Uniwersytet im. Adama Mickiewicza w Poznaniu

\title{
Nie tylko do czytania: Váchalowska gra z ideą pięknej książki
}

\begin{abstract}
Martwiło mnie wielce, że mi Stivín pod każdym artykułem umieścił „uroczą” winietkę. Próbowałem interweniować, aby te filigranowe ornamenciki usunął, ale Stivín dowodził, że takie zdobienia wynikają z reguł typograficznych i że puste miejsca nie wyglądałyby pięknie. Mówił tak przekonująco, że się w końcu zgodziłem, chociaż mi się to nie podobało (Karásek ze Lvovic 1994: 96)ํ․․
\end{abstract}

Wspominając początki publikowania czołowego czeskiego modernistycznego czasopisma „Moderní revue” (1895-1924), jego współredaktor naczelny (obok Arnošta Procházki) Jiří Karásek ze Lvovic koncentruje uwagę wokół kłopotów towarzyszących negocjacjom, które początkujący wówczas wydawcy zmuszeni byli podejmować z właścicielami drukarni, z niechęcią przyglądającymi się rozmaitym edytorskim nowinkom, stanowiącym konsekwencję prób wdrażania w życie coraz popularniejszej na przełomie xIx i xx wieku idei „pięknej książki”2. Konieczność oddawania rękopisów w ręce przedsiębiorców, niejako

1 Wszystkich tłumaczeń z języka czeskiego dokonała autorka artykułu.

2 Recepcja tej idei w Czechach wiąże się przede wszystkim z działającą w latach 1895-1925 oficyną wydawniczą Knihovna Moderní revue (Biblioteka „Moderní revue”) oraz (również „spokrewnionymi” z czasopismem) publikacjami: kierowaną przez Kamillę 
„Z natury rzeczy” zainteresowanych przede wszystkim osiągnięciem zysku i dysponujących zestandaryzowanymi narzędziami i technikami zecerskiej produkcji, zmuszała co prawda obie strony do poszukiwania kompromisowych rozwiązań i do rezygnacji (przynajmniej częściowej) z maksymalistycznych wyobrażeń o modernizacji typograficznych konwencji i nawyków, ale - z innej perspektywy patrząc - owocowała zarazem stopniowym owych nawyków przekształcaniem i - w rezultacie - popularyzacją nowej, secesyjnej w warstwie wizualnej i dekadencko-symbolistycznej w sferze światopoglądowej strategii obrazotwórczej (zob. Wittlich 1986: 115-116).

W roku 1905 w eseju Kniha jako umélecké dílo (Książka jako dzieło sztuki) najbardziej wpływowy czeski krytyk literacki, F.X. Šalda, zaniepokojony diagnozowanym przez siebie upadkiem kultury wydawniczej (podobne utyskiwania przewijały się zresztą wówczas w wypowiedziach wielu europejskich reformatorów kultury i zwolenników estetyzacji życia), w nieco patetycznym tonie nawoływał: „Niechaj księga będzie dzisiaj dziełem sztuki, jak nim bywała niegdyś, w szczęśliwszych epokach kultury naszej, a jest nim znowu w sztuce bardziej kulturalnych narodów, zwłaszcza w Anglii, tej ojczyźnie klasycznej kultury wydawniczej" (Šalda 1951: 13)3.

W tym samym czasie debiutował Josef Váchal (1884-1969), grafik, malarz i pisarz mianujący siebie przede wszystkim drzeworytnikiem, konsekwentny outsider (i w swojej epoce „wielki nieobecny”) dwudziestowiecznej kultury czeskiej ${ }^{4}$. Aczkolwiek wszystkich dziedzin, w których ten ekscentryczny „po-

Neumannową serią Knihy dobrych autorů (Książki Dobrych Autorów; 1905-1931) i wychodzącymi z inicjatywy Hugona Kosterki książkami w ramach edycji Symposion. Knihy nové doby (Symposion. Książki z Nowej Epoki; 1898-1914) (zob. Zach 1995: 222-245; Bohatcová 1990: 397-405). Osobno przypomnieć wypada wydawnictwo Dobré dílo (Dobre dzieło; 190o-1941); jego funkcjonowanie wpisuje się w działalność ośrodka kultury katolickiej Stará říše, którego założycielem był filozof i tłumacz literatury francuskiej i angielskiej, Josef Florian (Med 2004: 69-74).

3 Tekst ten został opublikowany jako artykuł wstępny w czasopiśmie „Typografia” (1905) redagowanym przez jednego z czołowych czeskich reforatorów kultury wydawniczej, Karla Dyrynka (1876-1949), autora opracowania Krásná kniha. Její technická úprava (Piękna książka. Jej przygotowanie techniczne, 1909) (zob. Bohatcová 1990: 412-417).

4 Ową szczególną predylekcję artysty do drzeworytnictwa najlepiej, być może, scharakteryzował Jiří Olič w monografii Neznámy Váchal. Život umělce (Nieznany Váchal. Życie artysty, 200o): „Váchal jest twórcą szczególnego typu. Nie czuje się ani pisarzem, ani malarzem. Maluje i pisze przez całe życie, ale jest przekonany, że podstawy jego artystycznej tożsamości leżą gdzie indziej. Sam siebie nazywa drzeworytnikiem, nie w tym jednakże sensie, że chciałby się zdefiniować jako wykonawca jednej tylko tech- 
liartysta" próbował swych sił, nie sposób niemal wyliczyć, to jednak, jak pisze Marie Rakušanová, w centrum jego zainteresowań leżała idea autorskiej, a zatem (w nawiązaniu do typologii Gérarda Genette’a) autograficznej - w całości (od tekstu po oprawę introligatorską) wykonanej przez jednego twórcę - książki5 W tak rozumianej praktyce edytorskiej „Váchal urzeczywistniał romantyczny ideał czystego dzieła sztuki, które rodzi się ze spontanicznej potrzeby kreacji” (Rakušanová 2014b: 19). Większość badaczy rozpatrujących Váchalowską działalność księgarską podkreśla jej związki z secesyjnym uniwersalizmem, Wagnerowskim pojęciem Gesamtkunstwerk oraz z konceptem the book beautiful ${ }^{6}$.

Koncept ten, zrodzony w refleksji teoretycznej (i urzeczywistniony w rękodzielniczej praktyce ruchu Arts and Crafts) Williama Morrisa, Johna Ruskina i Waltera Crane’a, bazując na skrajnie negatywnej ocenie narastającego procesu industrializacji, zakładał powrót do produkcji rękodzielniczej czy manufaktu-

niki graficznej, ma raczej na myśli wcielenie się w mityczną rolę człowieka, który ryje $w$ drewnie $i$ w ludziach. W drzeworycie i drzeworytnictwie odnalazł własny wyraz i sens pracy artystycznej. Wypracował różnież specjalną technologię tworzenia i używał jej podczas pracy przy każdej autorskiej książce” (Olič 200o: 135).

5 Jak rekapituluje Anna K. Folta-Rusin: „W Lœuvre de l’art., 1: Immanence et transcendence Genette, opisując poszczególne artefakty ze względu na sposób ich istnienia w kulturze, wyróżnia porządek autograficzny, do którego należą dzieła sztuki postrzegane jako obiekty materialne posiadające jedno stałe materialne «ciało», oraz porządek allograficzny, do którego zalicza dzieła postrzegane jako obiekty idealne. Pierwsze z nich powstają w trakcie jednego stadium tworzenia, co oznacza, że artysta tworzy dzieło ostateczne [...]. Drugie powstają w ramach dwóch stadiów tworzenia: produkcji tekstu (pisanie) i jego wykonania, realizacji (druk, odtworzenie głosowe, adaptacja teatralna, filmowa itp.)" (Folta-Rusin 2020: 17).

6 Por. „Najwyraźniej obecność secesji - zarówno doprowadzona do skrajności, jak i przezwyciężona - widoczna jest w Váchalowskim pojmowaniu książki. Autonomiczna twórczość wydawnicza najprecyzyjniej definiuje jego artystyczny i duchowy profil. Punktu wyjścia należy w tym przypadku dopatrywać się w secesyjnym ideale pięknej książki, u którego źródeł stoją projekty prerafaelitów zainspirowanych przez Williama Blake’a i postulujących syntetyczny «plastyczny» wygląd książki. [...] Tutaj także przecina się większość dziedzin artystycznych budujących całe spektrum Váchalowskich praktyk twórczych. Jego księga stanowi syntezę sztuki graficznej (wykraczającej jednak poza ramy konwencjonalnej książkowej ilustracji), pracy introligatora, zecera i typografa, nierzadko wzbogaconej o projektowanie oryginalnych pięknych czcionek oraz, przede wszystkim - kreacji literackiej. W ten sposób Váchalowska księga staje się - całkowicie w duchu secesji - Gesamtkunstwerkiem w dosłownym sensie, wytworem skrajnie indywidualnym i unikatowym na tle ówczesnego europejskiego kontekstu" (Hůlek 1990: 308). 
rowej, tylko ona gwarantowała bowiem przywrócenie przedmiotom należnego im piękna, dawała współczesnemu człowiekowi szansę odzyskania estetycznych walorów egzystencji i - w ostatecznym rozrachunku - pozwalała na realizację dekadenckiej utopii utożsamienia sztuki z życiem. Odpowiednio zdobione książki do owej powtórnej (w refleksji prerafaelitów przeszłość, przede wszystkim średniowieczna, urastała do rangi niedoścignionego ideału) estetyzacji ludzkiego otoczenia przyczyniać się miały nie tylko dzięki rzemieślniczej staranności wykonania, lecz także w wyniku zharmonizowania układu graficznego tekstu z obrazem we wspólnej, budowanej zgodnie z regułami architektoniki, koherentnej całości’. Przywołanie aparatu pojęciowego z dziedziny architektury w funkcji metaforycznego narzędzia opisu rozwiązań wydawniczych znajduje potwierdzenie zarówno w mediewistycznych fascynacjach Morrisa, proklamującego, że „jedynym dziełem sztuki doskonałością przewyższającym średniowieczną księgę, pozostaje doskonała średniowieczna budowla” (cyt. za: Šalda 1951: 14), jak i w rozważaniach Waltera Crane’a, który, pośrednio łącząc koncepcję pięknej książki z równie popularnymi na przełomie xıx i xx wieku projektami idealnego „domu artysty”, przypominał, że:

Myśl i wzrok dzielą świat sztuki między siebie - nasze myśli podążają za tym, co widzimy, a to, co widzimy, przechodzi przez filtr naszych myśli. Książka może być domem zarówno dla myśli, jak i wzroku. Mówiąc metaforycznie, w odniesieniu do książkowego zdobnictwa niektórym

7 Charakteryzując Morrisowską „modelową” książkę, Grzegorz Bąbiak podkreśla, że „każdy z jej elementów: litery, winiety, bordiury, jak i połączona w jednolitą, spójną całość ilustracja, przyczyniał się do stworzenia dzieł samych w sobie. Książki Morrisa były zatem w mniejszym stopniu użytkowe, w większym zaś artystyczne w wielorakim tego słowa znaczeniu. Zyskiwały dzięki temu autonomię, która dotychczas była zarezerwowana tylko dla niektórych dziedzin sztuki. Stawały się elementem jego szerszego estetycznego zamysłu, w którym przedmioty otaczające człowieka estetyzowały jego przestrzeń i były dalekie od masowej sztampy" (Bąbiak 2013: 20). Mieczysław Wallis wpisuje zaś estetyzacyjne projekty Ruskina i Morrisa w przestrzeń dyskursu antycywilizacyjnego: „Bolała ich żmudność i nuda rozłożonej na drobne fragmenty pracy robotników, zadymienie, brud i smród dzielnic i osiedli przemysłowych; ogołocenie i zeszpecenie krajobrazu. W dziedzinie sztuki zaś - brzydota i pospolitość wytworów przemysłu artystycznego oraz zwyrodnienie rękodzieła artystycznego. Obaj tęsknie spoglądali wstecz. Marzył im się rzemieślnik średniowieczny, kowal, stolarz lub złotnik, który zarazem projektował i wykonywał swoje dzieło, który kształtował je w całości sam i w tym kształtowaniu znajdował radość najwyższą. Toteż dzieło jego było czystym i pełnym wyrazem jego osobowości i przeto piękne i wytworne” (Wallis 1984: 172). 
wystarcza prosta chata w lesie, bo najbardziej zależy im na jak najbliższym zewnętrznym kontakcie z naturą. Inni zaś wolą otoczyć dom ogrodem, potrzebują więc czegoś w rodzaju planu architektonicznego. Będą patrzeć na frontypis jak na fasadę; przyjmą gościnne zaproszenie strony tytułowej tak, jak przyjazną inskrypcję nad gankiem [...]; ujmą dłoń autora i prowadzeni dalej przez niego i projektanta jego książki będą przechodzić z pokoju do pokoju, jak przewraca się stronę za stroną udekorowaną i ozdobioną obrazami, ornamentami i wzorami. Znalazłszy to, czego potrzebuje, gość chętnie odpocznie przy kominku, w płonącym blasku ducha pisarza lub fantazji artysty [...] zapomni o wyboistej ścieżce życia i niespokojnym świecie na zewnąrz (Crane 2018: 173-174).

Kultywowana przez Váchala „misja” odrodzenia i rehabilitacji zapoznanych technik graficznych niewątpliwie wiele zawdzięczała księgarskim doświadczeniom i osiągnięciom angielskich odnowicieli tradycji rękopiśmiennych iluminacji i inkunabułowej ksylografii, choć stosowane przez niego rozwiązania zyskiwały wymiar o wiele bardziej eksperymentalny i, można by zaryzykować twierdzenie, obrazoburczy ${ }^{8}$. Z jednej strony grafik zaakceptował bowiem program rehabilitacji rzemiosła i w całej twórczości starał się doskonalić (a zatem w modelowy sposób powielać) przejęte od średniowiecznych i barokowych kopistów, rytowników i drukarzy doświadczenia rękodzielnicze, z drugiej jednak strony radykalnie podał w wątpliwość, nierzadko ją ośmieszając, ornamentacyjną konwencję prerafaelitów, proponując w jej miejsce wyraźnie turpizującą i antyklasycystyczną tradycję ikonograficzną ludowego drzeworytu ${ }^{9}$.

8 Zdaniem Marceli Mrázovej-Schusterovej, „o ile nowatorskie praktyki prerafaelitów ciążyły ku osiągnięciu ujednoliconego ładu artystycznego, realizowały konkretne reguły typograficzne i dążyły w efekcie do secesyjnej standaryzacji, o tyle Josef Váchal [...] pojmował pracę nad książką w sposób diametralnie odmienny: jako jedyną w swoim rodzaju okazję do indywidualnej, czasami aż przesadnie wyeksponowanej autoekspresji. [...] Váchal nigdy żadnych zasad nie respektovał, w swej księgarskiej twórczości je świadomie odrzucał" (Mrázová-Schusterová 1968: 7).

9 „Váchalowska poetyka przypomina średniowiecze, jego niebiańską chwałę i piekielną grozę. W pogardzanych wiekach średnich artysta odnalazł cechy bliskie własnej metodzie twórczej i własnemu pojmowaniu duchowości, średniowiecze pociągało go swą autentycznością i wewnętrzną prawdą, silniejszą niż w innych epokach ludzkich dziejów. Jeśli Váchal czegoś nienawidził, były to antyk i renesans. Europejski klasycyzm ze swym dążeniem do harmonii, pozostawiały go obojętnym, gotycką Váchalowską duszę interesowały i przyciągały skrajności” (Kroutvor 1994: 23). 
Wystarczy zresztą porównać wytwory oferowane przez Art and Crafts (wykształcone w jego ramach wzornictwo szybko zresztą przerodziło się w ogólnoeuropejską manierę zdobniczą) z Váchalowskimi, „jedynymi w swoim rodzaju” woluminami, by zauważyć widoczne na pierwszy rzut oka różnice i przyznać, (po części przynajmniej) rację Rakušanovej, twierdzącej, że:

Na podstawie znaczeniowego zróżnicowania lekturowych doświadczeń Váchal wysnuwał wnioski istotne dla własnej praktyki artystycznej. Nie stał się twórcą "pięknej książki”, której koncepcji w Czechach na przełomie wieków programowo poszukiwano. Błędy i uchybienia zecerskie, zakwestionowanie powszechnie respektowanych zasad wydawniczej estetyki i kultury, niezwykłe relacje łączące tekst z obrazem, niemal niemożliwy do odczytania kształt autorskich czcionek - oraz last but not least stylistyczna oryginalność z trudem zrozumiałej wypowiedzi - to były narzędzia, z którymi świadomie pracował, nadając im „nacechowanie semantyczne”. Totalne usensowienie tekstu i obrazu owocować miało unikalnym charakterem czytelniczych przeżyć, każdy kolejny kontakt z Váchalowską książką oferuje dzięki temu całkowicie nowe doświadczenie recepcyjne. W trakcie procesu pokonywania przeszkód, które autor stawia między odbiorcą a tekstem, znaczenie wytwarzane jest stale od nowa (Rakušanová 2014b: 5-6).

Zamiast charakterystycznych dla Morrisowskich publikacji eleganckich floratur i cyzelowanych, precyzyjnie portretowanych postaci w dziełach Váchala dominują toporne (dosłownie: jakby toporem wyciosane), pozornie nieporadne i prymitywistyczne w swej proweniencji, uproszczone metody obrazowania i deformowania rzeczywistości. W obu przypadkach jednak zastosowanie starannie dobranych narzędzi typograficznych służy (w zamierzeniu służyć powinno) rehabilitacji dawnego księgarskiego rzemiosła, w obu też tekst, a zatem podstawowy element funkcjonalny (semiotyczny i semantyczny) każdej książki traci do pewnego stopnia czytelność (w Váchalowskim ujęciu w dużo większym zakresie), jego recepcja wymaga bowiem od czytelnika wysiłku i talentów niemal deszyfracyjnych. Odmiennie natomiast prezentują się motywacje sterujące ich artystycznymi decyzjami.

Morris i jego liczni zwolennicy czy późniejsi, zanurzeni już w dekadenckim światoodczuciu naśladowcy dążyli w pierwszym rzędzie do tego by, jak pisze Teresa Walas (jej wypowiedź odnosi się do ogólnych wyznaczników tzw. estetyki schyłkowej), 
uczynić sztukę nie przedmiotem wyjaśniania i rozumienia, lecz przedmiotem czystej i bezinteresownej kontemplacji, a tym samym nadać jej status wartości absolutnej. [...] Trzeba pamiętać, że piękno dekadenckie jest całkowicie świeckie, nie ma i nie potrzebuje żadnych metafizycznych uzasadnień. Opiera się przede wszystkim na wartościach formalnych [...], apeluje do zmysłów i do psychicznej wrażliwości. Nic się za nim nie kryje - ani prawda, ani dobro, ani tajemnica; jest nieprzeźroczyste i materialne, znaczy samo siebie i samego siebie tylko jest rewelatorem. [...] Dzieło sztuki nie jest [...] tworem społecznym, ani przewodnikiem wartości metafizycznych; jest owocem kunsztu i talentu, płodem dobrego smaku i wrażliwości estetycznej (Walas 1986: 64, 66, 67-68).

Innymi słowy, ważniejsze od tego, co tekst znaczy, o czym opowiada i jakie przesłanie wyraża, okazuje się to, jak wygląda książka, w której tekst ten zostaje zamieszczony. Doświadczenie wzrokowe, a zatem zmysłowy kontakt z przedmiotem, zaczyna dominować nad intelektualnym rozważaniem filozoficznych, etycznych czy (nawet) estetycznych walorów dzieła w owym przedmiocie zakodowanych. Książka „do oglądania” (również w postaci zamkniętego, stojącego na półce foliału) wkracza dzięki temu w świat sztuki użytkowej, wysoko cenionej przede wszystkim w środowisku artystów secesyjnych, pragnących narzucić swój model dekoratywności całemu otoczeniu współczesnego człowieka.

Związki Váchala z dziedzictwem secesji wydają się tyleż bezpośrednie i oczywiste (nieprzypadkowo zapewne Petr Wittlich wykorzystał jeden z najbardziej znanych obrazów malarza - Plán astrální - spiritistická sedánka z 1906 roku w projekcie okładki opracowania Česká secese), co skomplikowane i wymagające badawczych uzasadnień i dopowiedzeń. Od chwili debiutu (1900) bliższa mu była, co podkreślają wszyscy niemal historycy sztuki pochylający się nad jego dziełem, „szorstka” stylistyka ekspresjonizmu czy późniejszego kuboekspresjonizmu niż „uładzona”, wytworna falista linia Art Nouveau ${ }^{10}$. Josef Kroutvor,

$10 \mathrm{~W}$ podobnie złożony i rodzący pytania interpretacyjne sposób prezentują się relacje drzeworytnika z nurtami awangardowymi. Váchal tworzył bez przerwy niemal od początku xx stulecia do śmierci w roku 1969, w zasadzie nie zmieniając swych ikonograficznych predylekcji i metod graficznych. Ta szczególna inercyjność i przywiązanie do przyswojonych za młodu technik artystycznych spowodowała, że jego dzieła w swoim czasie pozostawały najczęściej niezauważane i sytuowały się na peryferiach dominujących tendencji. Do rzadkości należały wyrazy uznania, jakimi Váchala obdarzył światowej sławy malarz, Alfred Kubin, który w liście do Františka Holešovskiego (1944) 
mianując twórcę „artystą książki w najgłębszym znaczeniu tego słowa” (Kroutvor 1994: 25), przypomina jednak, że

Publikacja jest dla Váchala przestrzenią, w której grafik projektuje swe wizje i fantasmagorie. Pełna uroku, niekiedy naiwna, ale zawsze poetycka książka jawi się mu jako szczęśliwe objawienie małej komety w bezgranicznym, nieludzkim wszechświecie. Secesja nie tylko nie uznawała bariery między sztuką wysoką i użytkową i między poezją i sztukami plastycznymi, ale nie oddzielała także obrazu od słowa. Wszystko przenikała ta sama siła twórcza, z najdrobniejszego ornamentu rozwijała się kosmiczna spirala. [...] Váchal również postępuje w podobny sposób, oswobodzony z karbów typograficznych schematów tekst stanowi tło dla rysunku, który dopowiada to, co sugeruje lektura. Nie jest to zatem ilustracja w zwykłym znaczeniu tego pojęcia, podejście Váchalowskie ma bardziej kreatywny i holistyczny charakter. Ale Váchal nie byłby sobą, gdyby się nie odżegnał od wzorców i nie znalazł własnych środków wyrazu. Zamiast zaokrąglonych, eleganckich czcionek sięgnął po kanciaste, niezgrabne liternictwo średniowiecznej gotyki, oczywiście własnoręcznie wykrawane. Książka sprawia archaiczne

w entuzjastycznym tonie pisał: „Drogi Przyjacielu, osłupiałem! Váchal, mistyczny cykl najwyższej rangi, zrodzony z naszej epoki - w prostej linii z Apokalipsy świętego Jana, przez Dürera, Blake’a i wielu innych. I ta doskonała ekspresyjna forma, ludowy drzeworyt. To znakomite dzieło przynosi mi pocieszenie, dodaje mi odwagi w tych dniach, które uważałem już za stracone. Dla moich własnych wizji dzieło to stanowi impuls, pozwala mi jak w świetle błyskawicy ze zdumieniem poczuć ludzką wspólnotę. [...] Co Pan o Váchalu wie? Jego nieposkromiona odwaga w dążeniu do rozbicia form doczesności mi imponuje! Czy Váchal jest także poetą, a nie tylko grafikiem, czy może jedno i drugie naraz? Nie zdziwiłoby mnie to, taki przecież był Blake!” (cyt. za: Olič 20oo: 139). Sporadycznie wypowiedzi na temat jego twórczości pojawiały się też w opracowaniach naukowych. W roku 1933 na przykład Václav Vilém Štech w relatywnie życzliwym duchu konstatował, że Váchal „uprawia prymitywny drzeworyt, na pierwszy rzut oka toporny, ale odpowiadający okultystycznemu przesłaniu jego tekstów, sugestywnie ukazujący straszydła i ponure wizje, zamieszkujące duszę artysty. Potrafi także uchwycić osobisty i emocjonalny wymiar uduchowionego pejzażu. Drukuje kilka kolorów z jednej matrycy równocześnie, a więc barwy te poniekąd muszą spływać, ale ta nieprecyzyjność przydaje pewnego uroku jego archaicznej formie, odległej w sensie intelektualnym i technicznym od przyjętych dziś metod artystycznych" (Štech 1933: 22). Dopiero po roku 1989 w atmosferze "przyśpieszonej” recepcji postmodernizmu rozpoczęło się „odzyskiwanie” Váchalowskiej tradycji, polegające między innymi na znalezieniu dla niego „właściwego” miejsca wśród prądów awangardowych (kubizmu, ekspresjonizmu i surrealizmu). 
wrażenie, przypomina odnaleziony stary, zapomniany rękopis, ale i to dzieje się intencjonalnie; gdyby Váchal zataił swe autorstwo, można by mówić o artystycznej mistyfikacji (Kroutvor 1994: 28).

Stylizacyjne ambicje (niewątpliwie skądinąd kojarzące się ze stanowiącymi rzekomo „znak rozpoznawczy” kultury czeskiej mistyfikacjami) ekscentrycznego grafika znalazły, należy powtórzyć, najpełniejsze odzwierciedlenie w jego imponująco bogatej pod względem ilościowym (obejmującej kilkadziesiąt tytułów) i z punktu widzenia podejmowanych przez autora tematów i technik plastycznych (na zasadzie swoistej „jedności w wielości”) bardzo różnorodnej praktyce księgarskiej. Obok własnych traktatów okultystycznych i podręczników ksylograficznych oraz prze-pisywanych ezoterycznych, heretyckich i/lub jarmarcznych, „pokątnych” najczęściej druków sprzed wieków publikował tė̇ teksty eseistyczne, poetyckie i powieściowe, opatrując je ilustracjami czy raczej uzupełniając sensy przekazywane przez zapisany tekst znaczeniami generowanymi dzięki płaszczyźnie obrazowej i czyniąc dzięki temu ze swych książkowych artefaktów przedmioty recepcji - w pełni rozumienia tego pojęcia - intersemiotycznej. Jeżeli bowiem rację ma Ewa Szczęsna, która ogranicza kategorię intersemiotyczności wyłącznie do wytworów operujących jednocześnie różnymi systemami znakowymi oraz (w innym miejscu) nadaje takim wytworom atrybut tożsamości hybrydycznej uspójniającej heterogeniczność zestawianych ze sobą dyskursów, to edytowane przez Váchala woluminy uznać można za wzorcowe egzemplifikacje tak rozumianych wzajemnych znakowych relacji ${ }^{11}$. Zarówno

11 Badaczka, stawiając tezę, że w tworzeniu znaczeń udział biorą różne semiosfery (i media), podkreśla, że „możliwe powinno być [...] wyodrębnienie figur zakotwiczonych w innych niż język systemach semiotycznych, a także tych, które powstają w interakcji różnych systemów znakowych. Oznaczałoby to w konsekwencji możliwość podziału na figury monosemiotyczne, a więc figury słowa, obrazu czy dźwięku, oraz intersemiotyczne powstające w relacji między odmiennymi systemami znakowymi. Poetyka polisemiotyczna oznaczałaby badanie kreacji tekstów polisemiotycznych - tworzonych przy współudziale więcej niż jednej semiosfery” (Szczęsna 2004a: 30-31). Rodzi się w ten sposób tożsamość hybrydyczna, czyli „tożsamość dyskursu, który ukształtowany został na drodze łączenia elementów uważanych początkowo, tzn. zgodnie z dotychczas obowiązującymi normami kształtowania tekstu za niespójne. W momencie jednak, gdy między zestawianymi formami nawiązana zostaje «nić porozumienia tekstowego», dochodzi do przełamania hybrydy na rzecz ukształtowania się tożsamości. Warto zauważyć, że tam, gdzie pojawia się tożsamość, nie może być mowy o hybrydzie i odwrotnie, hybrydyczność implikująca niestałość, nieokreśloność, pozostaje w sprzeczności z tożsamością, nazywającą bycie tym samym, zakładającą jakąś identyczność. Pojęcie tożsa- 
zapisane słowo, jak i towarzyszące mu obrazy, łączące się w nierozerwalną całość (między innymi dzięki temu, że karta książki stanowi odbitkę jednej matrycy drzeworytniczej), współistnieją w jego dziełach w swoistej symbiozie, korespondując ze sobą nie tyle w płaszczyźnie semantycznej, ile w sferze wizualnych walorów układu graficznego.

W poradnikowym opracowaniu Detal w typografii Jost Hochuli pisze, że:

Trudno czytelne kroje pisma, używane oszczędnie i umiejętnie, mogą przykuć uwagę czytelnika (lub oglądającego), zaszokować go, sprowokować i poprzez to skłonić do dokładniejszego przyjrzenia się i przyswojenia pozostałej części przekazu werbalnego i wizualnego. [...] Czytelnicy dłuższych tekstów, a przede wszystkim osoby czytające książki, zajmują konserwatywne stanowisko w kwestii kroju pisma. Odrzucają eksperymentalne rozwiązania dotyczące liter [...]. Takich czytelników nie interesują litery jako takie. Nie chcą oni widzieć „pięknej” czy „interesującej” czcionki, lecz zrozumieć sens zobrazowanych przez nie słów (Hochuli 2018: 10).

Tymczasem Váchal, całkowicie ignorując podobne pouczenia i przestrogi, doprowadził do paradoksalnej, jak to określa Marcela Mrázová-Schusterová, sytuacji, a mianowicie

sam swe książki uczynił nieczytelnymi: z jednej strony ze względu na ich utrudnioną dostępność, a w niektórych przypadkach uniemożliwiający lekturę ciężar woluminu i nierozpoznawalność oryginalnych czcionek, z drugiej strony zaś - z powodu stylistycznej ekscentryczności tekstów. Dzięki temu Váchalowskie książki stały się publikacjami bibliofilskimi par excellence, książkami przeznaczonymi wyłącznie do oglądania (Mrázová-Schusterová 1968: 6).

Jedną z głównych przyczyn owej dominacji „oglądalności” Váchalowskich foliałów nad ich „czytelnością” badaczka odnajduje w innowacyjnej czy kreatywnej inwencji; drzeworytnik nie tylko czerpał ją z zasobów średniowiecznego i barokowego liternictwa (włączając namysł nad ich „wtórną" - by tak rzec,

mości hybrydycznej [...] oddaje relację istniejącą między zakotwiczonymi w przeszłości normami nazywania a tym, co dokonuje się we współczesnej tekstualności. [...] Cechą współczesnych tożsamości hybrydycznych jest ich polisemiotyczny i multimedialny charakter" (Szczęsna 2004b: 326). 
pośrednio przywołując Łotmanowskie pojęcie systemów modelujących - funkcjonalnością w typograficzne dyskusje środowisk awangardowych ${ }^{12}$ ), lecz także tworzył czcionki oryginalne, dążąc do tego, by ich kształt korespondował (czy raczej integralnie się jednoczył) z semantyką tekstu ${ }^{13}$.

Stosowana przez Váchala strategia maksymalnego „udziwniania” kształtu liter daleko jednak wykracza poza dążenie do swoistego ich „odznakowienia” i odebrania im roli arbitralnego, „przezroczystego” signifiant służącego „bezproblemowemu” docieraniu do domeny signifié. Choć jej, sygnalizowane w badaniach, konsekwencje w postaci zakłócania płynności odbioru nie budzą wątpliwości (większość Váchalowskich tekstów rzeczywiście czyta się, czy raczej: odszyfrowuje, $\mathrm{z}$ trudem), to jednak czysto wizualne aspekty pisma, transformujące je w dysponujący odmiennym kodem semiotycznym i przeznaczony wyłącznie „do patrzenia” wytwór z dziedziny sztuk plastycznych, nie leżą w centrum jego artystycznych poszukiwań. Ich źródła (i ambicje) kryją się dużo głębiej i sięgają bardzo poważnie przez artystę traktowanej tradycji okultystycznej, stanowiącej przedmiot jego całożyciowej fascynacji ${ }^{14}$. W efekcie, co zauważa Rakušanová:

12 Co ciekawe, analogiczne tendencje badacze dostrzegają w typograficznych eksperymentach „absolutnego wyznawcy” i propagatora awangardowej nowoczesności, Karla Teigego: „Pismo, napisy - coś, bez czego nie obywały się najbardziej indywidualne projekty Devětsilu - architektura wykorzystywała już od starożytności. Szczególnie wyraźnym elementem artystycznego planu architekta stało się pismo od początku $\mathrm{xx}$ wieku. Twórcy secesji, neoplastycyzmu, puryzmu lub konstruktywizmu dbali jednakże o to, aby styl napisów na fasadach nie kłócił się ze stylem całego budynku. [...] Nie ukrywali nawet swego zamiłowania do anachronicznych rodzajów kursywy i antykwy, na jakie konstruktywistyczni typografowie lat dwudziestych patrzyli jako na formy schyłkowe. Podobne, zabarwione ironią postępowanie z przestarzałymi krojami pisma, znajdujemy w opracowaniach typograficznych autorstwa Teigego z pierwszej połowy lat dwudziestych. Owa ironiczna metoda pracy z pismem, pełna zamiłowania do sprzeczności między anachronizmem a nowoczesnością, nie ma chyba w twórczości innych europejskich architektów awangardowych tego okresu analogii” (Švácha 2005: 196).

13 Váchal podążał w tym zakresie śladem secesyjnego malarza, grafika i ilustratora, Vojtěcha Preissiga (1873-1944), pierwszego czeskiego twórcy oryginalnego kroju liter. Celem jego projektu, jak przyznaje artysta, miało być „pismo niestandardowe i niepozbawione wyrazu, ale też bez zbytniej ekstrawagancji, które nie stanowiłoby jedynie naśladownictwa i reprodukcji klasyków; zamierzałem dzięki niemu wyrazić niechęć w stosunku do typowej obłości i ugładzenia powszechnie używanych liter. Zamiast tego usiłowałem osiągnąć doskonałe proporcje (a jest to niezwykle ciężkie zadanie)" (Bohatcová 1990: 409).

14 Najbliższe, jak dowodzi Marie Rakušanová, były mu neoplatońskie teorie Heinricha Corneliusa Agrippy von Nettesheim (Rakušanová 2014a: 7, 2014b: 27). 
Każda litera reprezentuje oryginalny autonomiczny znak, który wzbogaca magiczne przesłanie tekstu. Kształt Váchalowskich czcionek wydaje się bliski inwokacyjnym pieczęciom z grymuarów $\mathrm{z}$ ich funkcją zaklinającą, polegającą na instruowaniu adepta podczas aktywnego uczestnictwa w prastarym rytuale. Takie pojmowanie pisma wymaga od czytelnika aktywności. Váchal nie ulega potrzebie harmonijnego wyważenia tekstowych komponentów, przeciwnie - zmusza odbiorcę, by ostrożnie podchodził do zatartego niemal sensu obrzędu przyzywania piekła (Rakušanová 2014a: 158).

Jako (wy)znawca nauk tajemnych Váchal znakomicie orientował się w świecie reguł oddziaływania magicznego, z teorii symbolistycznych (budujących wszak za młodu jego artystyczną i filozoficzną tożsamośćc ${ }^{15}$ przejął też ideę artysty jako nieświadomego medium - „przekaźnika” impulsów płynących z przestrzeni transcendencji ${ }^{16}$. W traktacie Dokonalá magie budoucnosti (Doskonała

15 Okultystyczne inspiracje twórcy korespondują zresztą z metafizycznymi intuicjami symbolistów. Zdaniem Josefa Kotka: „Intelektualne i artystyczne środowiska odnajdują na początku xx wieku w spirytyzmie i teozofii dogodne narzędzie zastąpienia problemów związanych z religią i wiarą przeczuciem istnienia nieokreślonej Tajemnicy i dzięki temu sprawy związane ze śmiercią i zaświatami pragną uporządkować w system, który oferuje niezmierną głębię i objawienie prawdy. Oczywiście chodziło też o modę i upodobania ówczesnych wyższych sfer. Váchalowskie postrzeganie teozofii było jednak o wiele bardziej skomplikowane, a złożoność ta znajduje odzwierciedlenie zarówno w dziełach artystycznych, jak i w fakcie, że po różnych życiowych etapach wypełnionych wątpliwościami twórca (chociaż w indywidualnej wersji) ostatecznie stał się wyznawcą teorii teozoficznych" (Kotek 2008: 15; zob. Wittlich 1986: 137). Sam Váchal w Doskonatej magii prorokował zaś, że zrodzony w nadchodzącej, idealnej epoce „człowiek o harmonijnej konstrukcji duchowej” (Artysta-Mag): „dzięki swej pracy odnajdzie w magii naukę ścisłą; jej założenia mówiące o lustrzanym odbiciu kosmicznych Mocy świata materialnego i niewidzialnego wieloma więzami połączonych z magiem go o tym przeświadczą" (Váchal 1997: 81).

16 Specyficzne podejście grafika do spuścizny ezoterycznej, uwzględniające zarówno pełne jej respektowanie, jak i prawo twórcy do dokonywania na niej rozmaitych zabiegów parafrastycznych, a nawet ośmieszających, zmotywowało Petra Wittlicha do sportretowania Váchala jako spadkobiercy średniowiecznych „nurtów alternatywnej duchowości”, a nawet jako przedstawiciela w Bachtinowskim duchu rozumianej „kultury śmiechu”: „W jego twórczości także pojawia się popularna wówczas refleksja o artyście jako medium nieznanych sił. [...] Dlatego też zaczął się systematycznie zajmować magią jako narzędziem pozwalającym zapanować nad podstępnymi psychicznymi mocami. Z zapałem studiował stare źródła i pisma autorytetów. Stąd czerpał kuriozalną wie- 
magia przyszłości, 1922), który uznać wypada za swoistą summę i zwieńczenie Váchalowskich ontologicznych, epistemologicznych i estetycznych (sztuka w jego oczach przynależy do sfery działań okultystycznych, otwierających przed twórcą i odbiorcą możliwość bezpośredniego kontaktu ze sferą Absolutu) wierzeń i przekonań, grafik przyznawał, że:

Dopiero, gdy przystąpimy do pracy, nowe impulsy ze światów nas otaczających otrzymamy, wbrew wszelkiej logice ludzkiej i rozumowemu prawdopodobieństwu. Sam z siebie pojawi się sens, w pierwotnym planie niekoniecznie potrzebny, ale teraz głęboki i rzeczywisty, dający właściwy i nieoczekiwany rezultat: IMAGINACJA NIGDY NIEWYŚNIONA, W NAGŁYM PRZEBŁYSKU W DZIELE ZMATERIALIZOWANA, O KTÓREJ TWÓRCA NIE MA POJĘCIA, TAK SAMO JAK MEDIUM, CZYLI FANTOM MATERIALIZUJĄCY. [...] Ten rodzaj imaginacji, z trudem wytłumaczalnych, wpadających in medias res, zdarza się niezwykle rzadko, a jego znaczenia dla dzieła, ducha twórcy i odbiorcy nie da się porównać $\mathrm{z}$ imaginacją typową, choćby wyśnioną przez duchy wybitne [...]. ото JEST MISTYKA MAGów-ARTYSTów, imaginacją duchową tworzących świat tylko dla dusz o najbogatszej wyobraźni widzialny. Ten, kto zna sposoby, jakimi powstawały dzieła średniowieczne, [...] nie może odczuwać podziwu dla umysłów materialistycznych, niezdolnych do patrzenia oczyma stuleci (Váchal 1997: 65).

Księga, która reprezentować ma (w doskonały, o czym świadczy tytuł traktatu, sposób) ów „świat widzialny tylko dla dusz o najbogatszej mocy imaginacyjnej”, wyróżniać się powinna nie tylko bogactwem i głębią duchowego przesłania (zyskującego w tym przypadku status prawdy objawionej), lecz także odpowiadającą istocie tego przekazu, również znaczącą (a nie wyłącznie dekoracyjną!) szatą graficzną. Odpowiedniość ta nie ogranicza się zatem do zsynchronizowania „piękna wewnętrznego" z „pięknem zewnętrznym” (jak to ujmowali kodyfikatorzy koncepcji the book beautiful) (zob. Šalda 1951: 13-14; Arct

dzę, którą później wykorzystywał w swoich obrazach i książkach. [...] Satyrycznogroteskowemu temperamentowi, z którym przekształcał cały ten różnorodny materiał, by zaprezentować osobisty sposób postrzegania sfery religijnej, towarzyszyło jednak ludowe poczucie humoru i tendencja do trawestowania idei metafizycznych. $Z$ tej perspektywy patrząc, Váchal stanowił przykład swego rodzaju aktualizacji postawy, która już w średniowieczu i renesansie wytwarzała «drugą» kulturę, opozycyjną w stosunku do oficjalnej, dogmatycznej teologii chrześcijańskiej” (Wittlich 1982: 313-314). 
1926: 14), ale poszerza swój zasięg, obejmując również rytualno-demiurgiczny potencjał autentycznego (rejestrującego transcendentne impulsy) dzieła sztuki (zob. Rypson 1989: 43-90).

Michal Ajvaz, jeden z najwybitniejszych czeskich pisarzy postmodernistów i zarazem analityk współczesnej kultury i badacz spuścizny Váchalowskiej (jego twórczość stanowi zresztą „wdzięczny” przedmiot badawczego namysłu nad nowatorskim zastosowaniem zabiegów intersemiotycznych) w opracowaniu na temat pisarstwa Jorge Luisa Borgesa, opatrzonym znamiennym dla niniejszych rozważań tytułem Sny gramatik, záře písmen (Sny gramatyk, światłość liter, 2003), podkreśla, że:

W momencie rozkładu wszystkich wyższych warstw znaczeniowych, nagle dostrzegamy litery i pojmujemy nie tylko pismo, lecz także najgłębsze źródła wszelkiego sensu i bezsensu. To prawda, że źródło to staje się sterylne, o ile nie podejmuje gry ze znaczeniami z warstw wyższych, z morfologią i składnią, które światłość liter ustanowiła; ale w świecie, gdzie każdy natychmiast ucieka w pustynne rejony abstrakcji i przyszłości przedmiotów, goniąc za wyjaśnieniami - celami, pojęciami, dziedzinami nauki i ideami - nikt nie ma prawa stawiać zarzutów temu, komu wystarcza światłość pisma, kto siedzi i szczęśliwie słucha śpiewu wielkich liter, nie starając się nawet o zrozumienie napisu. Być może ze światłości tej wykrystalizują się nowe magiczne wyrazy i zdania, podczas gdy ze znaczenia słów, w których ucichła wibracja rodzenia się, nic już żywego nie powstanie (Ajvaz 2003: 190-191).

Niemal identyczne refleksje Ajvaz poświęca „rewelatorskim” technikom operowania pismem w księgarskiej produkcji Váchala, budując swoisty „wyobrażony trakt interpretacyjny” wiodący od intuicyjnych „prepostmodernistycznych" literackich i plastycznych eksperymentów rytownika do wzbudzających zainteresowanie poststrukturalizmu dzisiejszych gier ze semiosferą ${ }^{17}$.

17 Ajvaz pisze, że w Váchalowskich księgach „w procesy, które owocują powstaniem dzieła sztuki, wplata się proces czytania. Proces ten zwykle odbywa się w czasie [...] i pozostaje ukryty za znaczeniami czytanego tekstu. [...] Váchal w swych książkach obnaża czynność czytania, nadając jej charakter wydarzenia w ten sposób, że zakłóca gładką płynność, która to działanie najczęściej cechuje. Prowadzi do jego zahamowania i obdarza je własnym przebiegiem. [...] Pismo należy do tych oczywistych i tajemniczych zarazem sfer rzeczywistości, których nie zauważamy, choć je mamy nieustannie przed oczami. [...] Váchal, dzięki wizualizacji, kwestionuje niewidzialną oczywistość 
Marzenie o „wykrystalizowaniu się magicznych słów i zdań”, którym zaowocuje powtórna wizualicja pisma, powiązane zostaje z postulatem (potrzebą? koniecznością?) radykalnej „deautomatyzacji” procesu czytania, polegającej na wywikłaniu go z utartego nawyku natychmiastowego, bezrefleksyjnego de facto docierania do sensu i na zmuszeniu wzroku do zatrzymania się na kroju użytych (zaprojektowanych unikatowo) czcionek. Dzięki temu litery „ożywają” (zmartwychwstają?), by pełnić nowe funkcje - przede wszystkim transformować się w „znaki wyższego rzędu” (bliskie Barthesowskiemu rozumieniu mitu) (por. Barthes 2000: 239-266), które, nie tracąc swej pierwotnej, konwencjonalnej sygnifikacji, nabierają sensów nowych, bez mała mitycznych czy sakralnych. Warunkiem sine qua non odgrywania tych ról staje się zaś jednorazowość wykorzystania poszczególnych typów pisma. Po spełnieniu swego zadania, jak to Váchal w wierszu Autodafé liter demonstruje za pośrednictwem głosów personifikowanych czcionek pochodzących z różnych autorskich publikacji, matryce drukarskie powinny ulec zniszczeniu (konkretnie: przetopieniu w tyglu alchemicznym) i powrócić do pierwotnego - anasemicznego - chaosu, by móc się w tekstach kolejnych „odrodzić” w odmienionym kształcie.

Magiczny potencjał, który Váchal przypisuje działalności artystycznej, nie dotyczy oczywiście wyłącznie liternictwa. W jego utopijnym (zdecydowanie retrospektywnym) programie nobilitacji sztuki wydawniczej „ożywają” całe woluminy. Grafik bowiem „przez całe życie traktował książkę jak żywy organizm” (Rakušanová 2014b: 370), z jednej strony odnosząc to pojęcie do projektowanego przez niego „somatycznego”, sensualnego trybu odbioru dzieł, w którym udział biorą, oprócz wzroku, również wrażenia dotykowe (w quasi-przewodniku kulturowo-turystycznym Šumava umírající a romantická ${ }^{18}$ na przykład szorstkość - uzyskana przez pogniecenie - papieru odpowiada fakturze skał) oraz sugestie olfaktoryczne (Váchal opublikował w 1920 roku alegoryczny traktat Mystika čichu ${ }^{19}$ ). Z drugiej strony natomiast rekomendował czytelnikowi, by ten podczas lektury aktywizował rozmaite strategie recepcyjne (nie tylko

pisma [...]. Stawia nam na drodze przeszkody i spowalnia czytanie, zmuszając nas do spotkania z pomijanym na co dzień światem liter, światem, który może stać się dla nas objawieniem wielkiej jedności, gdzie każdy znak jest rzeczywistością, a każda rzeczywistość - znakiem. Pismo nagle traci swą zwykłą pokorę. [...] Nadal pełni funkcję nośnika znaczeń, pokazując jednocześnie, że znaczenia te nie są naszą bezproblemową własnością, zdradza, że stanowią część mrocznych procesów, wyrastających dopiero ze znakowej warstwy rzeczywistości, z miejsca, gdzie się porządek naszych języków dopiero formuje" (Ajvaz 1994: 228-234).

18 "Szumawa umierająca i romantyczna”.

19 „Mistyka węchu”. 
intelektualne i emocjonalne) i nie zaprzestawał pogoni za ciągle uciekającym, wielopłaszczyznowym, „totalnym” sensem, który - obdarzony atrybutami płynności czy ruchomości - nigdy nie daje się ostatecznie uchwycić. Zainspirowany własnymi doświadczeniami towarzyszącymi przeglądaniu demonologicznego podręcznika Antoine’a Augustina Calmeta, przyznawał:

Zaskakujące wszak okazało się, że za każdym razem, gdy podarowany mi egzemplarz [...] otwierałem, kolejność rozdziałów inną mi się wydawała, miejsc wcześniej przeczytanych odszukać nie mogłem, a i treść książki zawsze odmienną znajdowałem. Odkryłem później, że treść owa $[. .$.$] rozmaicie się przekształcała i przeinaczała, jak tylko czytać$ ją zaczynałem; zauważyłem, że w zależności od mego stanu ducha odpowiadał w księdze tej tekst nastrojom przeze mnie przeżywanym (Váchal 2012: 36) ${ }^{20}$.

W zakończeniu parodystycznej powieści Krvavý román. Studie kulturněa literárně historická (Krwawa powieść. Rozprawa kulturowa i historycznoliteracka, 1924), zgodnie z intentio auctoris "składającej hołd” brukowcom z najniższego piętra komunikacji literackiej, owa somatyczność kontaktu z wytworami sztuki doprowadzona została ad absurdum, w groteskowym duchu „udosłowniając” tytuł dzieła (będący jednocześnie określeniem genologicznym). Oto jeden z bohaterów tekstu, Mistrz (pełniący, obok grafika Paseki i malarza Fragonarda funkcję alter ego pisarza), wkraczając w progi Josefa Váchala, drzeworytnika ${ }^{21}$ :

Otworzywszy ciężkim kluczem drzwi tego domu grozy, w którym przebywał [...], odważnymi krokami zstępował po schodach do piwnicy. [...] Już od wejścia do mieszkania wyraźnie poczuł obrzydliwy odór krwi, który wydobywał się z przybytku Paseki. [...] Krew ta wy-

20 Podobną wizję Księgi „W ruchu” - tekstu nigdy nieukończonego i nieustannie zmienianego (wymazywanego, korygowanego, dopisywanego) przez odbiorców zaprezentował Ajvaz w insularnej utopii Zlatý věk (Złoty wiek, 2001), po raz kolejny dowodząc, że z Váchalem łączą go głębokie intertekstualne „powinowactwa z wyboru” (Ajvaz 2001: 171).

21 Na marginesie niniejszych rozważań pozostawić wypada zagadnienie zaskakującej tu - znów „prepostmodernistycznej” i całkowicie obcej obyczajom „producentów” autentycznej sensacyjnej literatury brukowej - antyiluzywności polegającej na obnażaniu chwytów narracyjnych, eksponowaniu ich sztuczności i umownego charakteru, wprowadzaniu sygnałów autotematyzmu oraz zakwestionowaniu ustalonych relacji zachodzących między fikcją a referencją. 
ciekała z gotowych arkuszy Krwawej powieści, a mogłoby jej być już ze cztery wiadra (Váchal 1990: 288, 298).

Wybór schematu fabularnego zeszytowej powieści sensacyjnej, czyli jednego z najbardziej skonwencjonalizowanych gatunków pisarstwa komercyjnego, jako podstawy tematyczno-kompozycyjnej dla zaoferowania czytelnikowi pastiszowo-parodystycznego „typu idealnego” tzw. krváku i poprzedzenie go dodatkowo „teoretycznym wstępem” (skądinąd, nie licząc szczególnej autorskiej - ironiczno-sarkastycznej - dykcji wyjątkowo jak na swoje czasy rzetelnym i nowatorskim) (por. Gawarecka 2012: 98-106) nie powinny dziwić.

Po pierwsze, Váchal jako zapalony kolekcjoner rozmaitych „druków pokątnych” (od pieśni jarmarcznej przez literaturę kolportażową po hermetyczne grymuary) miał okazję zarówno rozpoznać i zgłębić zasady konstrukcyjne rządzące ich strukturalnym porządkiem, jak i „docenić” prymitywizm dominujących w nich stylów graficznych ${ }^{22}$ :

Najstarsze, w istocie swej szlachetne powieści pełne bywały romantyzmu, różnorodnych obrazowych scenerii i szybkiej, filmowej wprost akcji; zdobione barwnymi litografiami, nierzadko po mistrzowsku wykonanymi przez artystów w rodzaju Gareisa, Tulki i innych, pozostają te książki ósemkowego formatu prawdziwymi skarbami czeskiej literatury. Patrząc na późniejsze rzemieślnicze ksylografie, możemy zdiagnozować brak duchowej głębi, sztuczność i przeciętność nowszych powieści, nieudolnie kamuflowaną za pomocą bezczelnego wykradania prac innych, oficjalnych literatów [...]. O ileż lepsze wrażenie robi już sam wygląd szacownego dzieła Vlasta, sirotek z Červeného hrádku, liczącego 2757 stron niż byle jaka bździna, np. Růženy Jesenskiej, choćby i była ilustrowana znakomitymi i błyskotliwymi drzeworytami F. Koblihy. Nie ma tu miejsca na drobiazgowe porównywanie obu wzmiankowanych książek, dość powiedzieć, że w oczach reprezentantów dzisiejszej sztuki współczesnej więcej uznania znalazłyby ilustracje do Vlasty aniżeli dzieło Koblihy (Váchal 1990: 43, 52).

W „studium kulturowo- i literaturoznawczym” stanowiącym wprowadzenie do Krwawej powieści autor nie unika zresztą wtrętów ekfrastycznych

22 Janina Wiercińska twierdzi, że badawczy namysł nad estetyczną funkcją książki w sensie wizualnego artefaktu nie zrodził się w kręgach naukowych, ale stanowił szczególny skutek uboczny fascynacji kolekcjonerskich (por. Wiercińska 1986: 16). 
potwierdzających słuszność tezy o awangardowej aktualności zamieszczanych w dziewiętnastowiecznych brukowcach ilustracji. Otóż na jednej z nich:

ukazany został człowiek z drabiny spadający (a że z okrzykiem spadał, tego z podpisu na dole się dowiadujemy), albowiem ta się złamała, co na obrazku widać. Dziwi nas jedynie, jak się złamać mogła, gdyż poprzeczna belka większa jest niż ciało spadającego. Tutaj najwyraźniej chodziło malarzowi o ekspresjonizm [wyróż. A.G.], aczkolwiek tenże jeszcze wówczas wynaleziony nie został (Váchal 1990: 52-55).

Drzeworyty, którymi Váchal opatrzył tekst powieści, ów „preekspresjonistyczny” charakter ilustracji potęgują, eksponując zarazem wrażenie inter- czy raczej transsemiotycznej artystycznej jednolitości (całkowitej symbiozy i przenikania się) warstwy słownej i płaszczyzny obrazowej oraz przyczyniając się do osiągnięcia efektu „strukturalnej wspólnoty sztuk” rodzącej się niezależnie od (ewentualnej) heterogeniczności i zróżnicowania tematów prezentowanych w domenach wizualnej i tekstowej ${ }^{23}$.

Po drugie, Váchal sięga po konwencje (malarskie i literackie) skrajnie „zsemiotyzowane”, opatrzone wiązkami ustabilizowanych i w tradycji kulturowej nadal respektowanych znaczeń: schematy „najniższego piętra” literackiej tandety, średniowieczną i barokową alegorykę czy symbole okultystyczne. Postępowanie takie pozwala mu na dokonywanie wielowarstwowych zabiegów transformacyjnych i na operowanie gotowymi już „prefabrykatami” (Rakušanová mówi nawet w tym przypadku o postmodernistycznej strategii apropriacji,

23 Jak bowiem dowodzi Seweryna Wysłouch: „Ważne są [...] nie tematy i motywy, ale operacje znakowe w procesie «przekładu» znaczeń. Znaki ikoniczne nie są «gorsze» od językowych, mogą tworzyć metafory i sugerować wieloznaczność. [...] Strukturalna wspólnota sztuk polega więc na obecności tych samych operacji intelektualnych, przeprowadzanych w różnym materiale: zestawiania i utożsamiania odrębnych zjawisk na zasadzie kontrastu lub analogii czy też deformowania: pomniejszania i powiększania, wyodrębniania itp. Wszystkie te operacje prowadzą do zmian znaczeniowych, unieważniają referencje i uruchamiają dodatkowe konotacje" (Wysłouch 2004: 23, 24). Analogiczne wnioski wysnuwa, rozważając zagadnienie skomplikowanych relacji łączących ilustrację z tekstem, Katarzyna Szewczyk-Haake: „Dzieło literackie i ilustracja, odmienne w warstwie ikonograficznej, mogą jednak [...] wykazywać podobieństwa na poziomie ikonologicznym, dające opisać się w kategoriach pewnej wspólnoty ducha; innymi słowy, mimo różnic ikonograficznych, pewne fenomeny literackie i artystyczne (tekst i ilustracja do niego) pozwalają zyskać wgląd w sedno kulturowego charakteru epoki”" (Szewczyk-Haake 2017: 245). 
por. Rakušanová 2014b: $2 \mathrm{O}^{24}$ ) po to, by przesuwając $\mathrm{w}$ cień wszelkie towarzyszące lekturze „standardowe" interpretacyjne dylematy, skierować uwagę odbiorcy w stronę znaczeń „utajonych”: magicznej mocy odpowiednio spreparowanego pisma, właściwie dobranego słowa i dostosowanego doń obrazu.

Opisując w zakończeniu Krwawej powieści ponurą atmosferę drzeworytniczego warsztatu Paseki, Váchal nieprzypadkowo wszak wykorzystuje okultystyczną terminologię i metaforykę:

Mentalna przestrzeń wokół zabarwiona była ciemnymi kolorami, jak to zwykle bywa przy podobnym napięciu myśli, dokładnie według reguł teozofii. W przestrzeni astralnej zbiegały się na to miejsce złośliwe duchy, takie, z którymi podczas żadnego seansu nie da się wytrzymać. [...] Stopniowo żałobna barwa aury [wyróż. A.G.] poczęła się rozrywać, przebijana przebłyskami karmazynu gniewu i zawiści (Váchal 1990: 292-293).

W badaniach nad Váchalowskimi "grami z transcendencją" analizowane bywa pochodzące z zasobu wyobraźni teozoficznej pojęcie aury, explicite zresztą przez artystę wykorzystywane zarówno w tekstach wyjaśniających istotę sztuki (odpowiadającej istocie makrokosmosu, ewentualnie ów makrokosmos wyrażającej lub w magicznym duchu go wcielającej), jak i w dziełach malarskich i graficznych. Traktowana jako „widzialny, (oczywiście tylko dla wtajemniczonych)

24 Stosowane przez Váchala „manewry zawłaszczające” rzeczywiście przywoływać na myśl mogą dezynwolturę, z jaką postmoderniści zwykli obchodzić się z cudzym dorobkiem kulturowym: „W wypadku tego, co Crimp nazwał «progresywną» apropriacją, można mówić o «wrogim przejęciu», które nie ma charakteru estetyzacji lub nobilitacji zawłaszczonego obiektu, ale stanowi krytyczną operację ujawniającą strukturę znaku obrazu (lub wizualno-dyskursywnego obiektu) z jego historycznym nawarstwieniem, motywacją stojącą za jego powstaniem oraz dyskursywnymi obramowaniami. Gest zawłaszczenia dokonywał się na rozmaitych polach i w zależności od artysty lokował się na kontinuum wskazującym skalę różnicującego przekształcenia” (Lipiński 2017: 22-23). W zakończeniu swych rozważań Filip Lipiński jednoznacznie łączy prawo do apropriacji z ponowoczesnymi ,grami z tradycją”. Tymczasem, co przypomina Wiercińska, zawłaszczanie w dziejach sztuki praktykowane było od zawsze, niekiedy zresztą wiązało się z niebezpieczeństwem utraty aury: „Średniowieczne treści pierwotnie odpowiadające celom liturgii, a zawarte w miniaturach i drzeworytach starych kodeksów, z biegiem historii i w rękach kolejnych kopistów i drukarzy przedostawały się do innych dzieł, nie zmieniając niekiedy nawet postaci, lecz ulegając przetworzeniu znaczeniowemu, nastawionemu na publiczność już innej epoki” (Wiercińska 1986: 11). 
znak istnienia rzeczywistości astralnej aura (barwna poświata emanująca ze wszystkich ziemskich - ożywionych i nieożywionych - bytów naturalnych) stanowiła w oczach grafika przekonujący argument w quasi-naukowym dowodzeniu realnego istnienia rzeczywistości nadnaturalnej (zob. Rakušanová 2014a: 227-241).

Swój, przejęty z zasobu wyobraźni teozoficznej, koncept aury Walter Benjamin wiązał, jak wiadomo, ze swoiście rozumianą sakralnością sztuki (również w sensie „teologii negatywnej”, w którą przeradzała się idea l'art pour l'art). Jego zdaniem bowiem (warto przypomnieć):

Pierwotne zaszeregowanie dzieła sztuki w kontekst tradycji znajdowało swój wyraz w kulcie. Najstarsze dzieła sztuki, jak wiemy, powstały w służbie rytuału; najpierw magicznego, a potem religijnego. Jest więc rzeczą pierwszorzędnej wagi, że dzieło sztuki - z racji aury, stanowiącej nieodłączny atrybut jego istnienia - nigdy nie uwalnia się całkowicie od swej funkcji rytualnej. Inaczej mówiąc, jedyna w swoim rodzaju wartość autentycznego dzieła sztuki ma swoje podłoże w rytuale, w którym posiadało ono swą oryginalną i pierwszą wartość użytkową (Benjamin 1975: 210).

Ową aurę dzieło sztuki traci, gdy zostaje poddane procesowi reprodukcji, a zatem powieleniu i oddzieleniu od macierzystego kontekstu ${ }^{25}$. Niezależnie od oceny tych kulturowo-cywilizacyjnych przekształceń „bilans zysków i strat” może się bowiem w tym przypadku przechylać ku obu biegunom wyodrębnionej przez filozofa antynomii - trudno nie zauważyć, że Benjaminowskie postrzeganie auratyczności pokrewne jest Váchalowskim utyskiwaniom nad upadkiem autorytetu sztuki w świecie współczesnym:

Sztuka zawsze była, jest i zapewne w innym kształcie pozostanie istotnym elementem ludzkiego społeczeństwa. Dostępna dzisiaj dla wszyst-

25 „W interpretacjach refleksji Benjamina pojęcie aury najczęściej utożsamiane jest ze sposobem istnienia dzieła sztuki. Tu auratyczność, wywodząca się z nieautonomicznego istnienia dzieła sztuki, pozostającego na służbie kultu lub rytuału, rozumiana jest jako czynnik orzekający o autentyczności i oryginalności dzieła sztuki. Możliwa jest do odczytania tylko «tu i teraz». W przekonaniu filozofa aura - kontemplacyjne odczucie możliwe tylko w obecności oryginału, doświadczenie, w którym zatopiona zostaje cała tradycja - zanika w warunkach racjonalizacji świata. W miarę postępującej sekularyzacji sztuki, w miejsce wartości kultowej pojawia się nowa wartość, która określa jej stopień autonomii. Sytuację tę zmienia pojawienie się możliwości powielenia oryginału za pomocą metod technologicznych" (Frydryczak 2002: 165-166). 
kich, przynajmniej w formie reprodukcji, dociera do najodleglejszych zakątków. Jest jak ogień, z którego tysięce iskier wylatują, przez chwilę świecą i gasną. Sztuka czy raczej wcielone piękno w dziewięćdziesięciu procentach zdominowała wszystkie dziedziny codzienności, stała się częścią przemysłu i odziewa - już jako oczywistość - przedmioty codziennego użytku. Tylko o pozostałych dziesięciu procentach Sztuki, z której iskry wyskakują i gasną, mówimy jako o Sztuce prawdziwej, piszemy ją z wielkim $\mathrm{S}$ i umieszczamy w galeriach i publicznych kolekcjach. Jej twórcy i reprezentanci wyłamują się z myślenia stadnego i jako jednostki są, ze względu na abstrakcyjną wartość swej pracy, dla społeczeństwa w zasadzie bezużyteczni (Váchal 2013: 67) ${ }^{26}$.

Świadomy komplikacji towarzyszących opisywanej już „trudnej współpracy" twórców (dążących do uzyskania efektu innowacyjności) z oficynami wydawniczymi (nastawionymi na powielanie „sprawdzonych” rozwiązań), grafik stanowczo taką kooperację odradzał, motywując swą niechęć obawami związanymi z destrukcyjnymi dla podmiotowego wymiaru dzieła konsekwencjami rozpowszechniania się technik masowej reprodukcji:

Uczciwy artysta - drzeworytnik, który z tego czy innego powodu sam nie jest w stanie swych dzieł powielać, czuje wyraźnie, choćby rezultaty druku dzieła w wielkich oficynach prezentowały się znakomicie, że wiele z piękna i istotnych elementów jego pracy w ten sposób się zatraca, i szybko zanika w nim ów dreszcz rozkoszy, który podczas tworzenia drzeworytu go przenikał, ponieważ swego trudu nie doprowadził do końca. Boleśnie ranić go musi owo dążenie drukarni, by dzięki wielkiej liczbie rozmnożonego piękna dzieło popularnym uczynić. Nie pragnąłbym ujrzeć tak powielonej pracy mojej, spotykać jej na każdym rogu ulicy; dziesiątki tysięcy egzemplarzy indywidualnego graficznego dzieła, z jakimi dzisiaj mamy do czynienia, mnie mierzi; tak to artystyczne grafiki zmieniają sie w zwyczajne reprodukcje, ale nadal kosztują tyle, ile oryginał (Váchal 1934: 125).

Oddanie własnej pracy w cudze ręce skutkuje zatem nieuchronnym „wygaśnięciem” aury, to zaś oznacza, że reprodukowane dzieło sztuki traci moc magicznego oddziaływania, którą dysponuje „totalna”, promieniująca harmoniczną jednością znaczeń Váchalowska „ożywiona” księga. 


\section{| Bibliografia}

Ajvaz Michal (1994), Svět Josefa Váchala, w: Josef Váchal, red. Michal Ajvaz, Petr

Hruška, Jozef Kroutvor, Argestea, Praha, s. 153-242.

Ajvaz Michal (2001), Zlatý věk, Hynek, Praha.

Ajvaz Michal (2003), Sny gramatik, záře písmen. Setkání z Jorgem Luisem Borgesem, Hynek, Praha.

Arct Michał (junior) (1926), Piękno w książce, M. Arct, Warszawa.

Barthes Roland (200o), Mitologie, przeł. Adam Dziadek, Wydawnictwo KR, Warszawa.

Bąbiak Grzegorz P. (2013), Piękna książka na ziemiach polskich, „Sztuka edycji”, nr 2, s. 19-30.

Benjamin Walter (1975), Dzieło sztuki w dobie reprodukcji technicznej, w: tenże, Twórca jako wytwórca, przeł. Janusz Sikorski, Wydawnictwo Poznańskie, Poznań, s. 201-238.

Bohatcová Mirjam (1990), Česká kniha v proměnách století, Panorama, Praha.

Crane Walter (2018), O zdobnictwie książek dawnych i nowych, przeł. Agnieszka Chłoń i in., Universitas, Kraków.

Folta-Rusin Anna Kazimiera (2020), Twarz i ciało książki. Wizualne manifestacje tekstów a problemy interpretacji, Wydawnictwo Uniwersytetu Jagiellońskiego, Kraków.

Frydryczak Beata (2002), Świat jako kolekcja. Próba analizy estetycznej natury nowoczesności, Wydawnictwo Fundacji Humaniora, Poznań.

Gawarecka Anna (2012), Margines i centrum. Obecność form kultury popularnej $w$ literaturze czeskiej dwudziestolecia międzywojennego, Wydawnictwo Naukowe UAM, Poznań.

Hochuli Jost (2018), Detal w typografii. Litery, światła międzyliterowe, wyrazy, odstępy międzywyrazowe, wiersze, interlinia, łamy, przeł. Agnieszka Buk, d2d.pl, Kraków.

Hůlek Julius (1990), Návrat Josefa Váchala, w: Váchal Josef, Krvavý román. Studie kulturně a literárně historická, Paseka, Praha, s. 305-318.

Karásek ze Lvovic Jiř́i (1994), Vzpomínky, Thyrsus, Praha.

Kotek Josef (2008), Neuchopitelný Josef Váchal, Nová tiskárna Pelhřimov, Pelhřimov.

Kroutvor Josef (1994), K dílu Josefa Váchala, w: Josef Váchal, red. Michal Ajvaz, Petr Hruška, Josef Kroutvor, Argestea, Praha, s. 17-122.

Lipiński Filip (2017), Anatomia zawłaszczenia. Postmodernizm, procedury alegoryczne i mit, „Tekstualia”, nr 2, s. 21-44.

Med Jaroslav (2004), Spisovatelé ve stínu, Portál, Praha.

Mrázová-Schusterová Marcela (1968), Josef Váchal a kniha, Obolos, Praha. 
Olič Jiří (2000), Neznámý Váchal. Život umělce, Paseka, Praha.

Rakušanová Marie (2014a), Josef Váchal. Magie Hledání, Paseka, Praha.

Rakušanová Marie (2014b), Josef Váchal. Napsal, vyryl, vytiskl a svázal, Arbor vitae, Praha.

Rypson Piotr (1989), Obraz słowa. Historia poezji wizualnej, Akademia Ruchu, Warszawa.

Šalda F.X. (1951), Kniha jako umělecké dílo, w: Kritické projevy 6, red. Karel Dvořák, Praha: Melantrich, s. 13-18.

Štech Václav Vilém (1933), Moderní český dřevoryt, Hollar, Praha.

Švácha Rostislav (2005), Na czym polega oryginalność czeskiej awangardy architektonicznej „Dyskurs” nr 3, s. 190-208.

Szczęsna Ewa (2004a), Wprowadzenie do poetyki intersemiotycznej, w: Intersemiotyczność. Literatura wobec innych sztuk (i odwrotnie). Studia, red. Stanisław Balbus, Andrzej Hejmej, Jakub Niedźwiedź, Universitas, Kraków, s. $29-38$.

Szczęsna Ewa (2004b), Znak tekstowy w dyskursie kultury, w: Punkt widzenia $w$ tekście i dyskursie, red. Jerzy Bartmiński, Stanisława Niebrzegowska-Bartmińska, Ryszard Nycz, Wydawnictwo umcs, Lublin, s. 323-240.

Szewczyk-Haake Katarzyna (2017), Poza tematem. Uwagi o badaniu związków między tekstem literackim a ilustracja, w: Między dyskursami, sztukami, mediami. Komparatystyka jutra, red. Ewa Szczęsna, Piotr Kubiński, Marcin Leszczyński, Universitas, Kraków, s. 233-248.

Váchal Josef (1934), Receptář barevného dřevorytu, Josef Váchál, Praha.

Váchal Josef (1990), Krvavý román. Studie kulturně a literárně historická, Paseka, Praha.

Váchal Josef (2012), Jos. Váchala cesta Slovenskem s A. Calmetem, Ord. S. B. aneb Theorie vampyrismu, Gallery, Praha.

Váchal Josef (2013), O umění, „Umění. Art“, s. 66-74.

Walas Teresa (1986), Ku otchłani (dekadentyzm w literaturze polskiej 1890-1905), Wydawnictwo Literackie, Wrocław-Kraków.

Wallis Mieczysław (1984), Secesja, Arkady, Warszawa.

Wiercińska Janina (1986), Sztuka i książka, Pwn, Warszawa.

Wittlich Petr (1982), Česká secese, Odeon, Praha.

Wittlich Petr (1986), Umění a život. Doba secese, Artia, Praha.

Wysłouch Seweryna (2004), Literatura i obraz. Tereny strukturalnej wspólnoty sztuk, w: Intersemiotyczność. Literatura wobec innych sztuk (i odwrotnie). Studia, red. Stanisław Balbus, Andrzej Hejmej, Jakub Niedźwiedź, Universitas, Kraków, s. 17-28.

Zach Aleš (1995), Edice družiny Moderní revue, w: Moderní revue 1894-1925, red. Otto M. Urban, Luboš Merhaut, Torst, Praha, s. 222-245. 


\section{| Abstrakt}

\section{Anna Gawarecka}

\section{Nie tylko do czytania: Váchalowska gra z ideą pięknej książki}

Josef Váchal (1884-1969) - grafik, malarz i pisarz, przede wszystkim zaś drzeworytnik - uchodził za outsidera (i w swoim czasie „wielkiego nieobecnego”) kultury czeskiej xx wieku. Choć wyliczenie wszystkich dziedzin, w których działał ten ekscentryczny „poliartysta”, jest prawie niemożliwe, w centrum jego zainteresowań pozostawała idea książki w całości (od tekstu po introligatorstwo) wykonanej przez jednego artystę. Większość badaczy zajmujących się twórczością książkową Váchala podkreśla jej związki z secesyjnym uniwersalizmem, koncepcją Gesamtkunstwerk Wagnera i koncepcją pięknej książki. Stylizacyjne ambicje tego ekscentrycznego grafika znalazły najpełniejsze odzwierciedlenie w jego imponująco bogatej (kilkadziesiąt tytułów) i bardzo różnorodnej praktyce księgarskiej. Oprócz własnych traktatów okultystycznych i ksylograficznych prze-pisywanych ezoterycznych lub heretyckich „tajemnych” druków sprzed wieków publikował także dzieła eseistyczne, poetyckie i powieściowe, opatrując je ilustracjami, a raczej uzupełniając znaczenia nadawane przez teksty sensami generowanymi przez obraz, zamieniając książki $\mathrm{w}$ przedmioty wielopłaszczyznowego intersemiotycznego odbioru.

Słowa kluczowe: idea pięknej książki; secesja; tradycja ezoteryczna; intersemiotyczność; drzeworytnictwo

\section{| Abstract}

\section{Anna Gawarecka}

Not Only for Reading: Váchal's Game with the Idea of "Beautiful Books"

Josef Váchal (1884-1969), a graphic artist, painter and writer, primarily a xylographer, was considered as an outsider (and in his era "great absent") of the 2oth century Czech culture. Although it is almost impossible to enumerate all the areas in which this eccentric "multiartist" worked, however, at the center of his interests was the idea of a book entirely (from text to bookbinding) made by one artist. Most of the researchers who study Váchal's book-making activity emphasize its connections with secessionist universalism, Wagner's concept of Gesamtkunstwerk and the concept of "beautiful books". The stylizing ambitions of this eccentric graphic artist found their fullest reflection in his impressively rich (covering several dozen titles) 
and a very diverse book design. Apart from his own occult studies and xylographic textbooks and written esoteric or heretical "secret" prints from centuries ago, he also published essayistic, poetic and novel texts, providing them with illustrations or rather supplementing the meanings conveyed by the written texts with meanings generated by the image, turning his book artifacts into objects of the intersemiotic way of reception.

Keywords: the idea of beautiful books; secession; esoteric tradition; intersemiotism; xylography

\section{| Nota o autorze}

Anna Gawarecka - prof. nadzw. UAM, bohemistka, literaturoznawca, pracownik Instytutu Filologii Słowiańskiej Uniwersytetu im. Adama Mickiewicza w Poznaniu. Główne zainteresowania naukowe: czeska literatura i kultura: imaginarium narodowe, modernizm, postmodernizm, procesy umasowienia kultury, geografia kulturowa, intersemiotyczność. Opublikowała dwie monografie (Margines i centrum. Obecność form kultury popularnej w literaturze czeskiej dwudziestolecia międzywojennego, Poznań 2012; Wygnańcy ze światów minionych, Poznań 2007) oraz kilkadziesiąt artykułów poświęconych literaturze czeskiej xIx, xx i xxI wieku. E-mail: gawarecka@gazeta.pl ORCID: 0000-0002-0930-0064 
